

RESEARCH ARTICLE

\title{
INVITRO ANALYSIS OF AYURVEDA DECOCTION AND LIPID FORMULATION PREPARED FROM KRIMIGHNA MAHAKASHAYA GANA AGAINST DERMATOPHYTES.
}

1. Research officer (Ayu)CCRAS.

2. Professor SDM Ayurveda college Hassan.

3. Microbiologist SDM Ayurveda college Hassan.

\section{Manuscript Info}

\section{Manuscript History}

Received: 12 April 2019

Final Accepted: 14 May 2019

Published: June 2019

Key words:-

Kwatha,Sneha,Taila,Krimi,Krimighna

Mahakashaya gana.

\section{Abstract}

Many classical literatures are mentioned in Ayurveda and Charaka samhita is one among them.Charaka Samhita has mentioned 50 groups of drugs as Mahakashaya gana. Krimighna Mahakashaya gana is one among it which contains 10 drugs used against macrobes and microbes. However the dosage form in which this group of drugs has to be used is not clear. The liberty of deciding the suitable dosage form is left to the descretion of the physician.

Kwatha(Decoction) is a primary dosage form where the drugs are boiled with prescribed amount of water and reduced to specific amount. In this preparation water soluble active principles present in the drugs are extracted. When the Kwatha is processed with the drugs in Krimighna Mahakashayagana the attributes of the drugs will be transferred in to water media.

Taila(oil) are preparations in which oil is boiled with prescribed Kwatha(decoction) and Kalka(paste) of drugs according to the formulae for specific duration of time, fat soluble active principles of herbs will be transformed to oil media, which can be used internally as well as externally as specified. When the Taila(oil) is processed with the drugs in Krimighna Mahakashaya gana the attributes of the drugs will be transferred in to oil media.

Krimi mentioned in Ayurveda can be compared with microorganism and macroorganism. Among microorganisms, study of pathogenic Fungihas received only scant attention in comparison with other Pathogens. With the control of most Bacterial infections in the developed countries, fungal infection has assumed greater importance. Though anti microbial activity of some of the single constituent of above mentioned Krimighna Mahakashaya gana(Combination of 10 drugs) has been carried out, study of the whole group has not carried out. So to establish the Krimighna action w.s.r to anti fungal activity of the drugs of this group is taken up. Since the dosage form in which the medicine has to be administered is not clearly mentioned, two dosage forms namely Kwatha(decoction) and Taila(oil) are selected for present study. 


\section{Introduction:-}

Branch of Ayurveda which deals with the preparation of medicine is called Bhaishajya Kalpana.Bhaishajya means the medicine which treats diseases or controls it without any side effects ${ }^{1}$. Kalpana means the method by which various formulations are prepared and such formulation is also known as "Kalpa", the form attained will be suitable for body which enhances the health of the body ${ }^{2}$.

The role of Bhaishajya Kalpana in potentiating the drug action has been explained in Ayurveda. As per Ayurveda PanchaVidha Kashaya Kalpana like Swarasa(juice extract from herbal drugs), Kalka(drug paste), Kashaya(decoction), Hima(cold infusion) and Phanta(hot infusion) are considered as primary Kalpana and the base of all formulations ${ }^{3}$. Kwatha(Decoction) is a primary dosage form where the drugs are boiled with prescribed amount of water and reduced to specific amount. In this preparation water soluble active principles present in the drugs are extracted. Sneha Kalpana is a secondary Kalpana processed using primary Kalpana .It is a pharmaceutical procedure adopted to produce a medicament from the substances such as Kalka(Drug paste), Kwatha(decoction), and Drava Dravyas(liquid base) in specific proportions by subjecting them to specified heating pattern and duration. By this process, there happens a transformation of active therapeutic properties of the ingredients to the solvents, and hence, which helps in recovery of fat-soluble as well as water-soluble chemical constituents $\left.{ }^{[4,5}\right]$.Taila Kalpana (oil) is one form of Sneha Kalpana. Krimighna Maha Kashaya Gana ${ }^{6}$ is a group of ten drugs mentioned in books of Ayurveda against Krimi. It contains Akshiva(Moringaoleifera), Maricha (Piper nigrum), Gandira(Euphorbia antiquorum), Kebuka (Costusspeciosus),Nirgundi (Vitexnegundo), Vidanga (Embeliaribes), Kinihi(Achyranthesaspera), Swadamshtra (Tribulusterestris),Vrishaparni (Ipomea variety) and Akhuparni(Ipomeareniformis).Krimi ${ }^{7}$ mentioned in Ayurveda can be compared with microorganism and macro organism. Among microorganisms Fungal infection is a condition faced in present era, study of pathogenicfungi ${ }^{\mathbf{8}}$ has received only scant attention in comparison with other Pathogens. Hence an attempt is made to prepare KrimighnaKwatha(decoction from combination of 10 drugs) and Taila(oil preparation with 10 herbal drugs) and analyze using suitable parameters. And In vitro assessment of both the formulations for antifungal effect was also carried out with selected modern parameters.

\section{Methodology adopted}

The methodology of the present work was carried under following sections.

1. Pharmaceutical study

2. Analytical study

3. Experimental study

\section{Pharmaceutical study}

A. Collection of the drug

B. Authentication of the raw drugs

C. Preparation of the Krimighna Kwatha(decoction from drugs of Krimighna Maha KashayaGana ${ }^{\mathbf{6}}$ )

D. Preparation of the Krimighna Taila(oil preparation from Krimighna Maha Kashaya Gana ${ }^{6}$ )

\section{A. Collection of the drug:}

The total 10 raw drugs were collected among which 7 were dry drugs and 2 were wet drugs and instead of Vrishaparni, Akhuparni was taken in double quantity since Vrishaparni and Akhuparni is of same ipomea variety.The drugs required for the preparation of medicine were collected from Centre for Indian Medical Heritage (CIMH), Kanjikode Kerala india .

\section{B. Authentication of the drug}

The authentication of all the raw drugs was done at the Department of Dravyaguna, in Shri Dharmasthala Manjunatheshwara College of Ayurveda, Hassan.

\section{Preparation of Krimighna Kwatha: \\ Materials:}

Sieve size No 20-40, Stainless steel vessel of height- $9.5 \mathrm{~cm}$ depth $7.5 \mathrm{~cm}$, internal diameter $-15.5 \mathrm{~cm}$, Potable water, external diameter- $17.5 \mathrm{~cm}$ and circumference- $45 \mathrm{~cm}$ and thickness of $1 \mathrm{~mm}$, LPG stove and 10 drugs. 


\section{Methods:}

Fresh Krimighna Kwatha(decoction from drugs of Krimighna Maha KashayaGana ${ }^{\mathbf{6}}$ )was prepared at Shri Dharmasthala Manjunatheshwara Centre for Research in Ayurveda and Allied Sciences, Udupi Karnataka India and used for the study. Coarse powder of 7 dry drugs which passed through sieve no 20-40 was taken in quantity of 5 gm and 3 wet drugs were taken in double quantity $10 \mathrm{Gm}^{9}$. Processing of raw dry drugs was done at the Department of Rasashastra and Bhaishajya Kalpana, Shri Dharmasthala Manjunatheshwara College of Ayurveda Hassan. And wet drugs were crushed from Shri Dharmasthala Manjunatheshwara Centre for Research in Ayurveda and Allied Sciences, Udupi Karnataka india. The amount of water added was sixteen parts to that of total weight of all the ten drugs and it was reduced to one-eighth of the original quantity ${ }^{\mathbf{1 0}}$. To the mixture of all drugs $1040 \mathrm{ml}$ of potable water was added and kept for boiling in stainless steel vessel. The heating was done on LPG stove and level for reduction was checked by using a measuring scale. After the appropriate reduction of water the Kwatha(decoction)was filtered and used for in-vitro study.

\section{D.Preparation of Taila}

The preparation of Taila(oil) was done at the Department of Rasashastra and Bhaishajya Kalpana, Shri Dharmasthala Manjunatheshwara College of Ayurveda Hassan Karnataka. Steps adopted were:

1. Preparation of Krimighna Kwatha(decoction from drugs of Krimighna Maha Kashaya Gana ${ }^{\mathbf{6}}$ ) for Taila(oil prepared from drugs of Krimighna Maha Kashaya Gana ${ }^{\mathbf{6}}$ )

2. Preparation of Kalka (Drug paste)

3. Preparation of Taila(Medicated oil)

The process is explained below:

\section{Preparation of Krimighna Kwatha:}

Materials: Sieve size No 20-40, stainless steel vessel of height $25 \mathrm{~cm}$, depth of $25 \mathrm{~cm}$, internal diameter $37.5 \mathrm{~cm}$ and external diameter of $40 \mathrm{~cm}$, with thickness of $2 \mathrm{~mm}$ having circumference of $116 \mathrm{~cm}$, potable water, LPG stove, 10 drugs.

Methods: The preparation of Kwatha(decoction) was carried out at Department of Rasashastra and Bhaishajya Kalpana, Shri Dharmasthala Manjunatheshwara College of Ayurveda Hassan Karnataka. Coarse powder of 7 dry drugs of the Krimighna Mahakashaya(decoction from drugs of Krimighna Maha Kashaya Gana ${ }^{\mathbf{6}}$ ) which passed through sieve size no $20-40$, was taken in quantity of $100 \mathrm{gm}$ and 3 wet drug were taken in quantity of $200 \mathrm{gm}$. This mixture was added with $8000 \mathrm{ml}$ of potable water and kept for heating on LPG stove in a stainless steel vessel. The amount of water taken was eight parts of all drugs and reduced to one fourth of the total quantity ${ }^{\mathbf{1 1}}$. Water level for reduction was checked by using a measuring scale. Then the Kwatha(decoction) was filtered and used for preparation of Taila(oil).

\section{Preparation of Kalka (Paste):}

Materials: Sieve size No 100-120, Khalwayantra(mortar and pestle) -Depth-13cm, Thickness-4cm,Width-34cm, Breadth-21cm, Height-20cm, Pestle- $30 \mathrm{~cm}, 10$ drugs.

Methods: Kalka (Paste) was prepared from fine powder of 7 dry drugs and 3 wet drugs. All dry drugs were taken in quantity of $44 \mathrm{~g}$ and coarsely powdered in Khalwayantra(mortar and pestle)and finely powdered in mixer grinder along with wet drugs. The particles of the fine powder were of the sieve size No 100-120. 50 ml of potable water was used for preparation of Kalka (Paste) into a bolus. It was weighed to $83 \mathrm{~g}$ in wet state and used for the Taila Paka(oil preparation from Krimighna drugs).

\section{Preparation of Taila(oil):}

Materials: Stainless steel vessel of height $12 \mathrm{~cm}$, depth $11.5 \mathrm{~cm}$, internal diameter of $21.5 \mathrm{~cm}$ and external diameter of $24.5 \mathrm{~cm}$ with a thickness of $1 \mathrm{~mm}$ and circumference of $64 \mathrm{~cm}$, LPG stove, Kalka of 10 drugs

Methods: The Kwatha(Decoction) and Kalka(Paste) prepared as above were used for the Taila Paka. 83g of Kalka (Paste), 1960ml of Kwatha(Decoction), and 500ml of Taila(oil) was used for Taila Paka(oil preparation from Krimighna drugs). The Taila Paka(oil preparation from Krimighna drugs) was done in a stainless steel vessel. LPG stove was used for the heating purpose. The mild flame was maintained during whole process. The changes in the Taila(oil) and Kalka(Paste) along with temperature changes were noted for every 15min. When the Taila (oil) attained $K_{\text {harapaka }}$ (when the oil imbibed active principles from the drugs) flame was stopped.The total time taken for completion of the Taila(oil) was 5hours and 15min. After that the Taila(oil) was filtered and amount of the Taila(oil) obtained was measured it was $460 \mathrm{ml}$, it was used for analytical and in vitro study. 


\begin{abstract}
Analytical Study
In the present study,Analytical evaluation of Krimighna Kashaya Churna(Powder repared from Krimighna MahakashayaGana ${ }^{6}$, Krimighna Kwatha (Decoction pepared from Krimighna MahakashayaGana ${ }^{6}$ and Taila(oil prepared from Krimighna MahakashayaGana ${ }^{6}$ ) is carried out to develop preliminary standards.
\end{abstract}

\title{
Experimental Study
}

For validation of Krimighna Kwatha( decoction prepared from Krimighna Mahakashaya Gana ${ }^{\mathbf{6}}$ )and Taila(Medicated oil) prepared from Krimighna Mahakashaya Gana ${ }^{6}$ In-vitro study was done by using the Dermatophytes for checking its efficacy. The genera Trichophyton, Microsporum, Candida, aspergillus and Epidermaphyton are the principle etiologic agents of the Dermatophytes ${ }^{13}$, Dermatophytosis ${ }^{\mathbf{1 4}}$ is a superficial fungal infection of keratinized tissues. The species used for present study is Trichophyton tonsurans ${ }^{15}$, Microsporum canis $^{15}$, Aspergillus niger ${ }^{15}$, Candida albicans ${ }^{16}$.

Anti microbial study types ${ }^{17}$ :

1. Diffusion test

2. Dilution test

\section{Diffusion test:}

Diffusion consists of two method i.e. Agar well diffusion, Agar disc

Diffusion

Agar well diffusion:

The Agar diffusion assay is one method for quantifying the ability of antibiotics, to inhibit microbial growth against test drug. A known quantity of micro- organism is grown on agar plate. The well is bored with help of borer, standard drug and test drug of desired concentration is poured in well. If the organism are susceptible to a particular antibiotic or a test drug, an area of clearing zone where organism are not capable of growing will be noted i.e. called a zone of inhibition. If the compound is effective against an organism at certain concentration, no colonies will grow and this is called the zone of inhibition. In general, larger zones correlate with smaller minimum inhibitory concentration (MIC) of antibiotic for that organism. Inhibition produced by the test is compared with that produced by known concentration of a reference compound.

\section{b) Agar disc diffusion:}

It is same as the previous method instead of wells, the disc are placed in agar media (both standard and test drug disc) later zone of inhibition is noted. The disc should not be placed closer than $24 \mathrm{~mm}$ in agar plate. Not more than 12 discs should be placed on a $150 \mathrm{~mm}$ plate. The disc must be pressed down with forceps to ensure complete contact with the agar surface.

\section{2) Dilution method:}

Serial dilution of the drug is prepared and inoculated with the test microbe. In the tube dilution method, serial dilutions of the drug in broth are taken in tubes and a standardized suspension of the test microbe which is inoculated. After overnight incubation, the minimum inhibitory concentration (MIC) is read by noting the lowest concentration of the drug that inhibits growth. In present study Agar diffusion method is followed to assess the samples for its activity.

\section{Material and method:-}

Materials:

A) Drugs:

Krimighna Kwatha(decoction from Krimighna Mahakashaya Gana), Krimighna Taila(Taila from Krimighna Mahakashaya Gana)

B) Micro- organism:

\section{Fungal organism:}

The Dermatophytes produce infection that involves the superficial layer of the body, including areas of the body, including the hair, skin and nails. Among them the organisms used for the study are Trichophyton tonsurans-MTCC CODE 8475, Microsporum canis-MTCC CODE-2820, Candida albicans-MTCC CODE 183, Aspergillus nigerMTCC CODE-10180 
Methods: Anti microbial activity was done by Agar - well diffusion method. Assessment through disc diffusion study was measured by following zones:

1) Sensitive zone

2) Intermediate Zone

\section{Agar well diffusion method}

Principle -

1. Diffusion of the drug from a cavity through the solidified agar layer of a petridish

2. Prevention of the growth of the added micro organisms in a circular area or zone around the cavity containing a solution of the drug

3. Place was cleaned in laminar air flow by using $70 \%$ ethyl alcohol and UV light was switched on for 20 minutes.

4. $15 \mathrm{ml}$ of the Sabouraud's agar media ,yeast extract dextrose media was poured uniformly over the sterilized petridish.

5. $1 \mathrm{ml}$ of Sabouraud's broth, yeast extract dextrose media containing the organism was added uniformly over petridish, mix well and allow the media to solidify

6. Six equidistant wells on the plate were made

7. Test were conducted for different volume of sample $(10,25,50,100$ and $150 \mu l)$ separately.

8. Seperately take 100 micro litre of Amphoterecin $b$, and fluconazole as standard

9. Incubation of all the petridishes .

10. Microsporum canis - Incubation was done for 10 days

11. Trichophyton tonsurans - Incubation was done for 7 days at $25^{\circ} \mathrm{c}$

12. Candida albicans- Incubation was done for 48 hours at $30^{\circ} \mathrm{c}$

13. Aspergillus niger- Incubation was done for 5 days at $25^{\circ} \mathrm{c}$

\section{Results:-}

Krimighna Kwatha(Decoction prepared from Krimighna Mahakashaya Gana ${ }^{6}$ ) and Taila(oil prepared from Krimighna Mahakashaya Gana ${ }^{6}$ ) did not show any zone of inhibition at 10, 25, 50, 100,150 $\mu$ concentrations on Aspergillus niger, Candida albicans, Microsporum canis,Trychophyton tonsurans. It is observed that activity of Standard drug Amphotericin B and Fluconazole is significant against microbes. And the standard drug Fluconazole showed zone of inhibition of $12 \mathrm{~mm}$ at $100 \mathrm{mg} / \mathrm{ml}$ and $10 \mathrm{~mm}$ at $100 \mathrm{mg} / \mathrm{ml}$ on Aspergillus and Candida albicans respectively. Standard drug Amphotericin B showed zone of inhibition of $09 \mathrm{~mm}$ at $100 \mathrm{mg} / \mathrm{ml}$ and $10 \mathrm{~mm}$ at 100 $\mathrm{mg} / \mathrm{ml}$ on Microsporum canis, and Trychophyton tonsurans respectively.

\section{Discussions:-}

Eventhough antimicrobial activity for the individual drugs of Krimighna Maha KashayaGana has been proved earlier, also the antibacterial activity and activity against intestinal worms for the formulation has been already proved.In present study the the formulation as a whole was ineffective against the fungal strains used. Reason may be Microorganism procured may be genetically resistant or virulent. The dosage and concentrations of the preparations adopted for the study may not be sufficient to overcome the virulence of organisms. The microbial load taken for the study might be too high for the dosage form .Dosage form adopted may not be effective for the present fungal strains. Dosage form adopted would be effective in bacterial strains or against intestinal parasites not against fungal strains.The study helped to generate pharmaceutical and analytical standards for Krimighna Mahakashaya Gana Churna, Kalka and Taila

\section{Conclusion:-}

The present dosage forms could be tried for other fungal strains for fetching positive results. This research would be an eye opener to restrict the Krimighna Mahakashaya Gana against dermatophytes.

\section{Declarations}

Ethical Approval and Consent to participate"Not applicable"

Consent for publication

Consent from main and corresponding authors are available .

Availability of supporting data"Not applicable"

Competing interests"Not applicable" 
Funding"Not applicable"

Authors contribution This is a Research work carried by Main author with the guidance from corresponding authors and send for publication with their approval.

Acknowledgement

Acknowledge the able assistance given by Dr.Govinda Sharma and Dr.Shashirekha for completing this research work and also to Dr.K.S.Dhiman for his valuable assistance for the publication.

Table 1:-Organoleptic features of Kwatha(decoction) and Taila(oil) Prepared from Krimighna Mahakashaya Gana(Combination of 10 drugs)

\begin{tabular}{|l|l|l|}
\hline Parameters & Kwatha(decoction) & Taila(oil) \\
\hline Colour & Brown colour & Greenish blue \\
\hline Odour & Characteristic & Pleasant \\
\hline Taste & Acrid & Acrid \\
\hline Consistency & Viscous & Highly Viscous \\
\hline
\end{tabular}

Table 2:-Physico-chemical parameters of Krimighna Mahakashaya Gana Kwatha Churna(Powder for decoction combination of 10 drugs)

\begin{tabular}{|l|l|}
\hline Parameters & \multicolumn{1}{|c|}{ Results $\mathbf{n}=\mathbf{3} \% \mathbf{w} / \mathbf{w}$} \\
\hline Loss on drying & 5.995 \\
\hline Total ash & 10.075 \\
\hline & \\
\hline Acid insoluble ash & 0.997 \\
\hline Water soluble ash & 2.495 \\
\hline Alcohol soluble extractive & 2.994 \\
\hline Water soluble extractive & 8.053 \\
\hline
\end{tabular}

Table 3:-Physico-chemical parameters of Krimighna Mahakashaya Gana Kwatha (Decoction prepared from combination of 10 drugs)

\begin{tabular}{|l|l|}
\hline Parameters Results & $\mathbf{n}=\mathbf{3}$ \% w/w \\
\hline Refractive index & 1.33669 \\
\hline Specific gravity & 1.0105 \\
\hline Viscosity & 2.7939 \\
\hline
\end{tabular}

Table 4:-Physico-chemical parameters of Krimighna Mahakashaya Gana Taila(oil prepared from combination of 10 drugs)

\begin{tabular}{|l|l|}
\hline Parameters Results & $\mathbf{n}=\mathbf{3} \% \mathbf{w} / \mathbf{w}$ \\
\hline Refractive index & 1.4697 \\
\hline Specific gravity & 0.9177 \\
\hline Viscosity & 83.9885 \\
\hline Rancidity & Fat is not oxidized \\
\hline Acid value & 1.9615 \\
\hline Saponification value & 154.3718 \\
\hline Unsaponifiable matter & 2.1526 \\
\hline Iodine value & 92.3921 \\
\hline Peroxide value & 7.5908 \\
\hline Boiling point & $258^{\circ} \mathrm{C}$ \\
\hline
\end{tabular}

HPTLC Documentation of the Preparations 

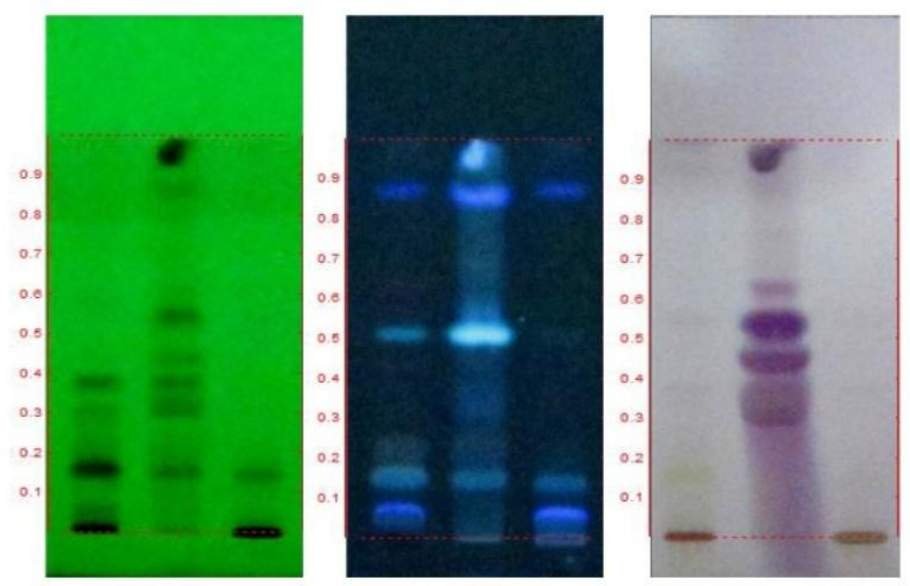

Track 1- Alcohol extract Krimigha Kashaya Churna prepared from drugs of Krimighna Maha Kashaya gana(Combination of 10 drugs)

(sample-1) - $8 \mu 1$

Track 2- Chloroform extract of Krimighna Taila(oil)prepared from drugs of Krimighna Maha Kashaya gana(Combination of 10 drugs)

(sample-2)- $8 \mu 1$

Track 3- Chloroform extract of Krimighna Kashaya(decoction) prepared from drugs of Krimighna Maha Kashaya gana (Combination of 10 drugs)

(sample-3)- $8 \mu 1$

Solvent system:

Toluene: Ethyl acetate (7:1)

Experimental study of the preparations on Dermatophytes.

I. Agar disc diffusion method adopted for Krimighna Kwatha (decoction) on Dermatophytes against Standard drug. In vitro study of Kwatha



Aspergillus niger

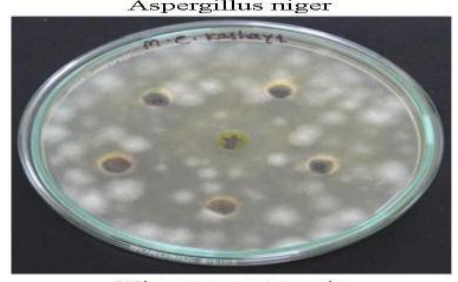

Microsporum canis

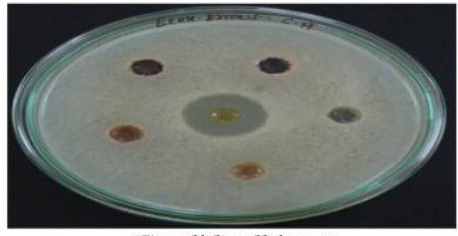

Candida albicans
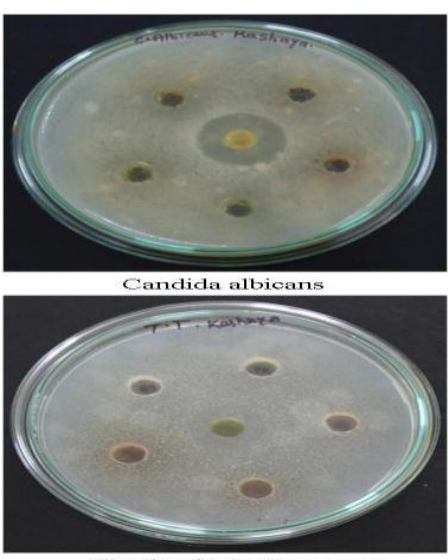

Trychophyton tonsurans Mighna Mahakashaya Churna 
II. Agar disc diffusion method adopted for Krimighna Taila (oil) on Dermatophytes against Standard drug

In vitro study of Taila

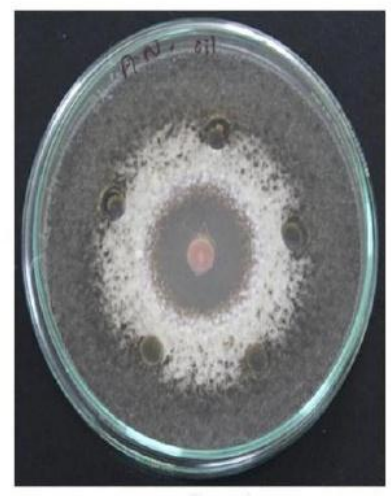

Aspergillus niger

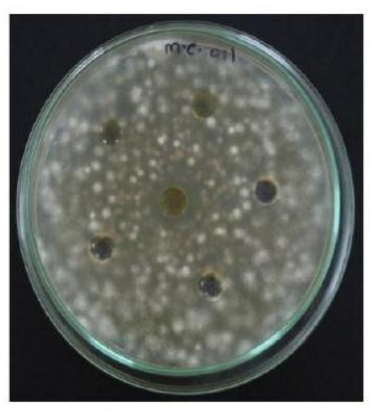

Microsporum canis

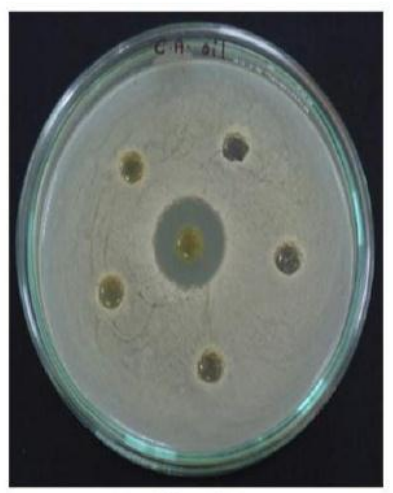

Candida albicans



Trychophyton tonsurans

\section{References:-}

1. Acharya Jadavaji Trikamji. Charaka Samhita. 9th ed.Varanasi. Chaukhambha Orientalia; 2011.p. 23.

2. Raja Radha Kanta deva. Shabdakalpadruma. 3rd ed.Varanasi. Chaukhambha Sanskrit sanskrit series office; 1967 vol III.p 543.

3. Tripathi Brahmanand Sarngadhara Samhita. 1st ed.Varanasi: ChaukhambaSurbharati Prakashan; 2006.p.125.

4. Karande, N., \& Desai, S. (2017). Concept of taila kalpana in ayurvedic pharmaceutics "a critical review". Ayurline: IJ-RIM, 1(01), 55-62.

5. Sahrangadhara. Sharangadhara Samhita, Madhyam Khand 7/194. 6th ed. Varanasi: Chaukhmaba Orientalis; 2005. p. 398, 137.

6. Acharya Jadavji Trikamji. Charaka Samhita Ayurveda Deepika commentary ofChakrapani Datta. Reprint ed. Varanasi (India): Chaukhambha Orientalia ; 2011:33Acharya Jadavji Trikamji. Charaka Samhita Ayurveda Deepika commentary ofChakrapani Datta. Reprint ed. Varanasi (India): Chaukhambha Orientalia ; 2011:258Ananthanarayan .R. Jayaram Panicker C K J .Medical mycology. In:(eds.) Textbook of microbiology. 5th ed. Madras: Orient Longman; 1996. p.567-569

7. Pandit Sarngadharacharya.Paribhasha.In:Pandit,Parasurama Shastri Vidyasagar(ed.)Sarngadhara Samhita.Varanasi:Chaukhambha orientalia;2012.p.11.

8. Pandit Sarngadharacharya.Kwatha Kalpana.In:Pandit,Parasurama Shastri Vidyasagar(ed.)Sarngadhara Samhita.Varanasi:Chaukhambha orientalia;2012.p.144.

9. Pandit Sarngadharacharya.Sneha Kalpana.In:Pandit,Parasurama Shastri Vidyasagar(ed.)Sarngadhara Samhita.Varanasi:Chaukhambha orientalia;2012.p.212.

10. Pandit Sarngadharacharya.Sneha Kalpana.In:Pandit,Parasurama Shastri Vidyasagar(ed.)Sarngadhara Samhita.Varanasi:Chaukhambha orientalia;2012.p.214.

11. David greenwood et. al ,Medical microbiology A guide to microbial infection.

12. 16th ed .Edinburgh London: Churchill livingstone ; 2002.p.572.

13. Chakraborthy.P. A textbook of Microbiology. 2nd ed. Kolkata: New CentralBook Agency; 2009. p.621-623. 
14. Betty A. Forbes, Daniel F. sahm. Bailey and scotts Diagnostic microbiology.12th edi. St. Louis Missouri: Westline industrial drive( MOSBY ELSEVIER);2007.p.663.

15. Satish Gupte, Short Textbook of Medical Microbiology,6thedi.NewDelhi:JaypeeBrothers Medical Publishers(p)ltd;1995.p.451.

16. Tendencia, E. A. (2004). Disk diffusion method. In Laboratory manual ofstandardized methods for antimicrobial sensitivity tests for bacteria isolated from aquaticanimals and environment (pp. 13-29). Tigbauan, Iloilo, Philippines: Aquaculture Department,Southeast Asian Fisheries Development Center. 